\title{
Studies on Gold Complexes. II. The Equilibrium between Gold(I) and Gold(III) in the Ammonia System and the Standard Potentials of the Couples Involving Gold, Diamminegold(I), and Tetramminegold(III)
}

\section{H. SKIBSTED* and JANNIK BJERRUM}

Chemistry Department I, Inorganic Chemistry, H. C. Ørsted Institute, University of Copenhagen, DK-2100 Copenhagen $\emptyset$, Denmark

The three standard potentials involving gold, gold(I), and gold(III) in the ammonia system are determined in $10 \mathrm{M}$ ammonium nitrate at $25^{\circ} \mathrm{C}$ by potential measurements with gold and platinum electrodes. The values obtained are

$\mathrm{Au}\left(\mathrm{NH}_{3}\right)_{2}++\theta^{-} \rightleftharpoons \mathrm{Au}+2 \mathrm{NH}_{3}$

$E^{0}{ }_{1,0}=+563 \pm 6 \mathrm{mV}$

$\mathrm{Au}\left(\mathrm{NH}_{3}\right)_{4}{ }^{3+}+2 \mathrm{e}^{-} \rightleftharpoons \mathrm{Au}\left(\mathrm{NH}_{3}\right)_{2}{ }^{+}+2 \mathrm{NH}_{3}$ $E^{0}{ }_{3,1}=+206 \pm 3 \mathrm{mV}$

$\mathrm{Au}\left(\mathrm{NH}_{3}\right)_{4}{ }^{+}+3 \mathrm{e}^{-} \rightleftharpoons \mathrm{Au}+4 \mathrm{NH}_{3}$

${E^{0}}^{0}=+\mathbf{3}=+3 \mathrm{mV}$

This leads to an equilibrium constant of $10^{-12.1}$ for the reaction $\mathrm{Au}\left(\mathrm{NH}_{3}\right)_{4}{ }^{3+}+2 \mathrm{Au}+2 \mathrm{NH}_{3} \rightleftharpoons$ $3 \mathrm{Au}\left(\mathrm{NH}_{3}\right)_{2}+$

and under certain assumptions to a cumulative stability constant $\beta_{2}=10^{26.5} \mathrm{l}^{2} / \mathrm{mol}^{2}$ for the diamminegold(I) ion.

The three standard potentials of gold couples involving gold, gold(I), and gold(III) have been determined for the chloride, ${ }^{1-3}$ the bromide, $4-6$ and for the thiocyanate systems. ${ }^{7-9}$ For several other gold systems the standard potential of the gold(I), gold couple is also known, ${ }^{10,11}$ but no investigations of standard potentials for gold ammine complexes have been reported. Gold potentials for the aqua ions cannot be measured for the obvious reason that neither gold(I) nor gold(III) aqua ions exist in measurable amounts. This means that stability constants relative to

* Chemical Laboratory A, The Royal Danish School of Pharmacy. the aqua gold complexes cannot be directly determined; one can only measure the relative stability of one complex to another. In such a series of stability constants for gold complexes the place of gold ammines is unknown.

Several attempts have been made to estimate the standard potentials for the aqua gold couples and the stability constants relatively to aqua ions from extrapolations in the Periodic Table and from linear free energy relation. ships. ${ }^{11-14,{ }^{26}}$ Knowledge of the standard potentials for different ligand systems are therefore also of interest in order to increase our knowledge of the standard potentials of the aqua couples. The present investigation contributes to this purpose with a determination of the standard potentials of the gold ammines.

Equilibrium between metallic gold and its complexes is attained relatively slowly and equilibrium between gold(I) and gold(III) must be established before measurements with gold electrodes provide reliable values. Gold(I) will disproportionate in systems with gold(I) concentrations greater than the equilibrium concentration, and in systems with a gold(III) concentration greater than that of equilibrium the gold electrode will dissolve. In halide and pseudohalide gold systems with excess of ligand the following equilibrium has been found to be dominating:

$\mathrm{AuX}_{4}^{-}+2 \mathrm{Au}+2 \mathrm{X}^{-} \rightleftharpoons 3 \mathrm{AuX}_{2}^{-}$

Acta Chem. Scand. A 28 (1974) No. 7 
In the ammonia system the corresponding equilibrium would be:

$$
\mathrm{Au}\left(\mathrm{NH}_{3}\right)_{4}{ }^{3+}+2 \mathrm{Au}+2 \mathrm{NH}_{3} \rightleftharpoons 3 \mathrm{Au}\left(\mathrm{NH}_{3}\right)_{2}+
$$

However, as discussed below, the situation turns out to be a little more complicated in the ammonia system than in the aniono systems.

The tetramminegold(III) ion is a robust complex and a weak acid with $\mathrm{p} K_{\mathrm{a}}=7.48$, but subject to hydrolysis and further decomposition especially at high $\mathrm{pH} .{ }^{16}$ The present investigation was therefore carried out in $10 \mathrm{M}$ ammonium nitrate in order to make it possible to have a sufficiently high ammonia concentration without greatly increasing the $\mathrm{pH}$. In this way reliable values for the standard potentials involving $\mathrm{Au}\left(\mathrm{NH}_{3}\right)_{2}+$ and $\mathrm{Au}\left(\mathrm{NH}_{3}\right)_{4}{ }^{3+}$ could be obtained.

\section{EXPERIMENTAL}

Solutions and materials. The gold(III) complex used in all experiments was $\mathrm{Au}\left(\mathrm{NH}_{3}\right)_{4}\left(\mathrm{NO}_{3}\right)_{3}$, synthesized as described earlier. ${ }^{16}$ This complex was weighed into measuring flasks and dissolved in $10 \mathrm{M}$ ammonium nitrate solutions containing varying ammonia concentrations. The gold powder used was prepared by reduction of gold(III) chloride with sodium pyrosulphite. All other reagents were of Analytical Reagent quality and were used without further purification. Ion exchanged water, distilled from alkaline permanganate in an all quartz apparatus, was employed throughout.

Analytical determination. Total gold concen. trations were measured by atomic absorption spectrophotometry on a Perkin Elmer apparatus model 403 with a hollow cathode lamp using standard conditions. The standard gold solutions were prepared from the same gold salt and with almost the same concentrations as the solutions to be analyzed.

Electrodes and potential measurements. In the $\mathrm{Au}(\mathrm{III})-\mathrm{Au}(\mathrm{I})$ redox titration experiments a plate of platinum $(4 \times 4 \mathrm{~mm})$ was used as an inert metal electrode. Before use the platinum electrode was cleaned in concentrated nitric acid to which has been added one drop of concentrated hydrochloric acid and was then washed with water. During the titration experiments the platinum electrode became covered with a thin layer of gold. This coated platinum electrode was used as a gold electrode in the equilibrium experiments. The EMF titrations were carried out under nitrogen in a water thermostated cell at $25.0 \pm 0.1^{\circ} \mathrm{C}$. A Radiometer pH-meter model PHM 52 was used.

All potentials were measured relative to a saturated potassium sulphate mercurous sul- phate electrode to avoid traces of chloride in the solution of the complex. A Radiometer model $\mathrm{K} 601$ electrode was used and was measured relative to a $0.1 \mathrm{M}$ potassium chloride calomel before and after each measurement. The calomel electrode was prepared according to Gjaldb $: e k,{ }^{17}$ the potential of this electrode against the normal hydrogen electrode was taken to be $+335.6 \mathrm{mV}$ at $25.0^{\circ} \mathrm{C},{ }^{19}$ a value which was controlled by comparison with the silver-silver chloride electrode in $0.1 \mathrm{M}$ potassium chloride ${ }^{19,20}$ to be correct within one $\mathrm{mV}$.

The liquid junction potential between the 10 M ammonium nitrate-gold solutions and the saturated potassium sulphate solution of the reference cell was partly eliminated as the reference cell again was measured against the $0.1 \mathrm{M}$ calomel electrode with $10 \mathrm{M}$ ammonium nitrate as an intermediate solution. This reduces the total liquid junction potential to one between $10 \mathrm{M}$ ammonium nitrate and $0.1 \mathrm{M}$ potassium chloride. A diffusion potential which is believed to be very small as the ammonium and the nitrate and the potassium and the chloride ions, respectively, have almost identical ionic mobilities. No correction was therefore introduced for liquid junction potentials. This is also justified from the reproducibility of the potentials.

Gold potentials are generally reported $\mathbf{7 , 1 8 , 2 1}$ to be difficult to obtain with reproducible results because of a low exchange current and slow establishment of equilibrium in case of $\mathrm{Au}(\mathrm{III})$. The electrodes normally used are gold wires ${ }^{22}$ or platinum plates coated with gold by an electrolytical method.1,13 Gold electrodes without strain should be preferred, and the use of gold pieces or gold wires must therefore be avoided. If an electrolytical method is used to coat a platinum plate, a low current density must be chosen. $\mathbf{N}$. Bjerrum ${ }^{21}$ used a titration procedure like the one described here, starting with a smooth platinum electrode which during the titration is converted into a gold electrode, but did not point out the advantage of such a strainfree electrode.

$A u(I I I)-A u(I) r e d o x t i t r a t i o n$ with platinum electrode

Solutions of tetramminegold(III) nitrate $\approx$ $10^{-3} \mathrm{M}$ in $10 \mathrm{M}$ ammonium nitrate, with am. monia concentrations from $0.2 \mathrm{M}$ to $2 \mathrm{M}$, were titrated with hydrazine solutions with the same ammonium nitrate and ammonia concentrations as the complex gold solution. Hydrazine acts as a four electron donor in basic solutions, ${ }^{23}$ so the reaction with gold(III) under the conditions mentioned is supposed to be:

$4 \mathrm{OH}^{-}+\mathrm{NH}_{2} \mathrm{NH}_{2}+2 \mathrm{Au}\left(\mathrm{NH}_{3}\right)_{4}{ }^{3+} \rightarrow$ $2 \mathrm{Au}\left(\mathrm{NH}_{3}\right)_{2}{ }^{+}+\mathrm{N}_{2}+4 \mathrm{H}_{2} \mathrm{O}+4 \mathrm{NH}_{3}$

Acta Chem. Scand. A 28 (1974) No. 7 
Table 1. Titration of $\mathrm{Au}\left(\mathrm{NH}_{3}\right)_{4}{ }^{3+}$ in $10 \mathrm{M} \mathrm{NH}_{4} \mathrm{NO}_{3}$ and varying $\mathrm{NH}_{3}$ concentration with $\mathrm{NH}_{2} \mathrm{NH}_{2}$. The gold complex was dissolved in $20.0 \mathrm{ml}$ of the solvent medium and titrated with a solution of $\mathrm{NH}_{2} \mathrm{NH}_{2}$ in the same medium. The titrations were performed at $25.0 \pm 0.1^{\circ} \mathrm{C}$ under a nitrogen atmosphere. The potentials were measured with a platinum electrode and are given ( $\mathrm{mV}$ ) relative to the normal hydrogen electrode. From each titration experiment a mean value of the apparent standard potential ' $E^{0}=E-29.6 \log \left[C_{\mathrm{Au}(\mathrm{III})} / C_{\mathrm{Au}(\mathrm{I})}\right]$ was calculated. The standard potential $E^{0}{ }_{3,1}$ was calculated by means of the expression derived with $K_{\text {amid }}$ inserted (see text). The table gives the initial concentration of $\mathrm{Au}\left(\mathrm{NH}_{3}\right)_{4}{ }^{3+}, C^{0}{ }_{\mathrm{Au}}$ in $\mathrm{mM}$ and $C_{\mathrm{NH}_{3}}=\left[\mathrm{NH}_{3}\right]$ in $\mathrm{M}$. Full experimental data for titration No. 5 are given in Table 2. For the two experiments marked with an asterisk the final potential measured with a gold electrode (after an equivalent amount of $\mathrm{NH}_{2} \mathrm{NH}_{2}$ was added) is used to calculate $E^{0}{ }_{1,0}$; see Table 3 .

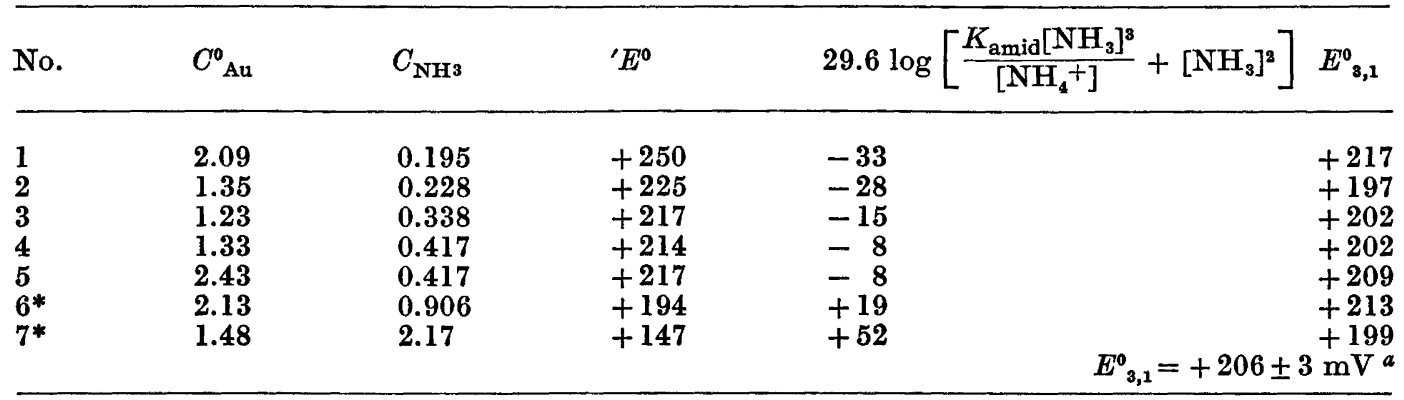

a It must be noted that this standard deviation applies to the mean value of the observed distribution under the assumption of a normal distribution. The standard deviation of the distribution itself is obtained from this figure by multiplication by the square root of the number of experiments. This remark applies also to the standard deviation of Tables 2 and 3.

Table 2. A typical titration experiment, No. 5 of Table $1.20 .0 \mathrm{ml}$ of a $0.00243 \mathrm{M} \mathrm{Au}\left(\mathrm{NH}_{3}\right)_{4}{ }^{3+}$ solution in $10 \mathrm{M} \mathrm{NH} \mathrm{NO}_{3}$ and $0.417 \mathrm{M} \mathrm{NH}$ was titrated with a $0.00130 \mathrm{M} \mathrm{NH} \mathrm{NH}_{2}$ solution containing the same ammonium nitrate and ammonia concentration. The titration was performed at $25.0 \pm 0.1^{\circ} \mathrm{C}$ under a nitrogen atmosphere. $18.7 \mathrm{ml}$ of the hydrazine solution is equivalent to the titrated gold(III).

\begin{tabular}{llllr}
\hline ml $\mathrm{NH}_{2} \mathrm{NH}_{2}$ & mmol Au(I) & mmol Au(III) & $E$ & $E^{0}$ \\
\hline 3.00 & 0.00775 & 0.0407 & +242 & $(+221)$ \\
4.00 & 0.0104 & 0.0381 & +235 & +218 \\
5.00 & 0.0130 & 0.0355 & +230 & +217 \\
6.00 & 0.0155 & 0.0330 & +225 & +215 \\
7.00 & 0.0181 & 0.0304 & +219 & +216 \\
8.00 & 0.0207 & 0.0278 & +216 & +215 \\
9.00 & 0.0233 & 0.0252 & +214 & +215 \\
10.00 & 0.0259 & 0.0226 & +211 & +216 \\
11.00 & 0.0285 & 0.0200 & +209 & +216 \\
12.00 & 0.0311 & 0.0174 & +217 \\
13.00 & 0.0337 & 0.0148 & +206 & +219 \\
14.00 & 0.0363 & 0.0122 & +205 & +220 \\
15.00 & 0.0388 & 0.0097 & & $\left(E^{0}=217 \pm 1 \mathrm{mV}\right.$ \\
\hline
\end{tabular}

The concentration of the tetramminegold(III) ion must be corrected for amido formation. The equilibrium constant for the reaction:

$$
\mathrm{Au}\left(\mathrm{NH}_{3}\right)_{4}{ }^{3+}+\mathrm{NH}_{3} \rightleftharpoons \mathrm{Au}\left(\mathrm{NH}_{3}\right)_{3} \mathrm{NH}_{2}{ }^{2+}+\mathrm{NH}^{+} \text {, }
$$

$K_{\mathrm{amid}}=\frac{\left[\mathrm{Au}\left(\mathrm{NH}_{3}\right)_{3} \mathrm{NH}_{2}{ }^{2+}\right]\left[\mathrm{NH}_{4}{ }^{+}\right]}{\left[\mathrm{Au}\left(\mathrm{NH}_{3}\right)_{4}{ }^{3+}\right]\left[\mathrm{NH}_{3}\right]}$

has been determined in $1 \mathrm{M}$ ammonium per. chlorate to be $97 .{ }^{16}$ An estimation using the salt dependence of the reaction: ${ }^{27}$

Acta Chem. Scand. A 28 (1974) No. 7 
$\mathrm{Co}\left(\mathrm{NH}_{3}\right)_{6}{ }^{3+}+\mathrm{H}_{2} \mathrm{O} \rightleftharpoons \mathrm{Co}\left(\mathrm{NH}_{3}\right)_{5} \mathrm{OH}^{2+}+\mathrm{NH}_{4}+$

gives for $K_{\text {amid }}$ in $10 \mathrm{M}$ ammonium nitrate the value $\approx 50$. The potential $E$ of the redox reac. tion:

$\mathrm{Au}\left(\mathrm{NH}_{3}\right)_{4}{ }^{3+}+2 \mathrm{e}^{-} \rightleftharpoons \mathrm{Au}\left(\mathrm{NH}_{3}\right)_{2}{ }^{+}+2 \mathrm{NH}_{3}$

with $K_{\text {amid }}$ included in the expression can be written:

$E={E^{0}}^{0}{ }_{3,1}+\frac{R T}{2 F} \ln \frac{C_{\mathrm{Au}(\mathrm{III})}}{C_{\mathrm{Au}(\mathrm{I})}}$

$-\frac{R T}{2 F} \ln \left[\frac{K_{\mathrm{amid}}\left[\mathrm{NH}_{3}\right]^{3}}{\left[\mathrm{NH}_{4}{ }^{+}\right]}+\left[\mathrm{NH}_{3}\right]^{2}\right]$

where $\left.C_{\mathrm{Au}(\mathrm{III})}=\left[\mathrm{Au}\left(\mathrm{NH}_{3}\right)_{4}\right)^{3+}\right]+\left[\mathrm{Au}\left(\mathrm{NH}_{3}\right)_{3^{-}}\right.$ $\left.\mathrm{NH}_{2}{ }^{2+}\right]$ and $C_{\mathrm{Au}(\mathrm{I})}=\left[\mathrm{Au}\left(\mathrm{NH}_{3}\right)_{2}{ }^{+}\right]$are the total concentrations of gold(III) and gold(I), respectively.

The results of the redox titration experiments are given in Table 1; full experimental details of one of the experiments are found in Table 2.

Discussion of the potential measurements. Hydrazine titrations of solutions with ammonia concentrations lower than $\approx 0.2 \mathrm{M}$ gave uncertain results. The potentials were stable only in the beginning of the titration, then they started drifting and gold precipitation first on the electrode then in the solution occurred. In titrations with ammonia concentrations higher than $\approx 0.2 \mathrm{M}$, the potentials obeyed the Nernst equation except in the beginning of the titration and near the equivalent points, and were stable within a few $\mathrm{mV}$. The higher the ammonia concentration, the more stable were the observed potentials. When an excess of hydrazine was added, the potentials started drifting and the platinum electrode was coated with a thin gold layer before the potentials were stabilized. Analysis of such a solution showed that the gold concentration was lowered by less than $2 \%$. In solutions with ammonia concentrations greater than $\approx 1 \mathrm{M}$ the potentials became stable overnight. The results of the titrations of tetramminegold(III) ion with hydrazine can be summarized as follows. With ammonia concentrations lower than $\approx 0.2 \mathrm{M}$, titration gives undefined results because the formed diamminegold(I) complex is not sufficiently stabilized towards disproportionation. Titrations with ammonia concentrations be- tween $\approx 0.2 \mathrm{M}$ and $\approx 1 \mathrm{M}$ followed reasonably well the Nernst expression, but after reduction of all gold(III) to gold(I) no final potential on the electrode coated with a thin layer of gold could be obtained. This was possible, however, in systems with ammonia concentration greater than $\approx 1 \mathrm{M}$. To assure that the gold couple and not a couple including the hydrazine is potential determining, a titration under the same conditions but without gold complex was performed. The potential obtained during such a titration drifted and showed that an irreversible hydrazine couple has no direct effect on the potential. This is also supported from the fact that there was no drop in the potential at the equivalent point like that to be seen in usual redox titrations. When all the gold(III) is converted into gold(I), the hydrazine as the part of an irreversible couple cannot give a defined potential. In the investigations on the gold aniono sys. tems, ${ }^{2,9,21}$ sulphite has been used as titrator in the experiments which were all carried out in acidic solutions. The sulphite ion coordinates strongly with gold(I) and gold(III) and therefore it cannot be recommended in basic solution. The choice of hydrazine in this investigation gives a reducing agent with approximately the same coordinating properties as ammonia. With ammonia present in excess it will have no influence on the complex formation.

If gold system is in equilibrium, the potentials of all of the three gold couples are identical. In the titrations with a platinum electrode only the equilibrium with respect to electron transfer between gold(III) and gold(I) at the electrode exists. Therefore the platinum electrode must be free of gold. With gold precipitated on the electrode, then this also responds to the gold, gold(I) couple. Lingane ${ }^{1,4}$ and Pouradier et al. ${ }^{2}$ have shown that in gold chloride and bromide systems not in equilibrium, the gold(I) will be the potential determining concentration on a gold electrode. This phenomenon can be correlated with the fact that while complex of gold(I) are labile, the gold(III) complexes are more robust. Further, it should be considered that the gold(I) complexes have a different configuration from that of the gold(III) complexes. It is therefore not, as might be expected, ${ }^{21}$ the gold(III),gold(I) couple but the exchange current of the gold(I) which determines the potential.

Acta Chem. Scand. A 28 (1974) No. 7 
Experiments with goldsolutions equilibrated with metallicgold

Experiments in order to try to establish equilibrium with metallic gold were performed as follows. A series of solutions of tetramminegold(III) nitrate in $10 \mathrm{M}$ ammonium nitrate with varying ammonia concentration were shaken with gold powder for 15 days. The change in gold concentration was followed with time. The gold concentration remained constant after about one week.

Another series was started with gold(I) initially present using solutions prepared from tetramminegold(III) nitrate which had been reduced with an equivalent amount of hydrazine. After a few hours the gold(I) disproportionated to some extent and a gold precipitate was formed. The solutions were allowed to equilibrate for four days, and the total gold concentrations were then determined.

The potentials of the equilibrated solutions were measured with a gold electrode generated in the titration experiments. The potentials became stable after about an hour. It was now assumed that $C_{\mathrm{Au}(\mathrm{I})}=\left[\mathrm{Au}\left(\mathrm{NH}_{3}\right)_{2}+\right]$ and $C_{\mathrm{NH}_{3}}=$ $\left[\mathrm{NH}_{\mathrm{s}}\right]$. The standard potential for the Au-
$\left(\mathrm{NH}_{3}\right)_{2}{ }^{+}$, Au couple is therefore given by the expression:

$E=E_{1,0}^{0}+\frac{R T}{F} \ln \left[C_{\mathrm{Au}(\mathbf{I})} / C_{\mathrm{NH}^{2}}\right]$

$C_{\mathrm{Au}(\mathrm{I})}$ was calculated from the knowledge of both the initial and the final total gold concentrations, $C^{0}{ }_{\mathrm{Au}}$ and $C_{\mathrm{Au}}$ (eq.), respectively. In Table 3 the compositions of the solutions are given together with the measured potentials and the calculated values for $E^{0}{ }_{1,0}$. The table contains the final potentials from the two titration experiments in solutions with ammonia concentration higher than $\approx 1 \mathrm{M}$. The uncertainty in $E^{0}{ }_{1,0}$ is relatively high but in fair agreement with the assumption that $\mathrm{Au}(\mathrm{I})$ is present as a diammine complex. The Nernstian plot given in Fig. 1 shows this directly.

\section{DISCUSSION OF RESULTS}

From the two standard potentials determined, $E^{0}{ }_{3,1}$ and $E^{0}{ }_{1,0}$, the third standard potential is given by the relationship

$3 E^{0}{ }_{3,0}=2 E^{0}{ }_{3,2}+E^{0}{ }_{1,0}$

Table 3. Potential measurements with a gold electrode in solutions equilibrated with metallic gold in $10 \mathrm{M} \mathrm{NH}_{4} \mathrm{NO}_{3}$ at $25^{\circ} \mathrm{C}$. All potentials are relative to the normal hydrogen electrode in $\mathrm{mV}$. Concentrations are in $\mathbf{M}$.

In solutions prepared from tetramminegold(III) ions the $C_{\mathrm{Au}(\mathrm{I})}$ are calculated from the initial gold concentration $C^{\circ}{ }_{\mathrm{Au}}$ and the "equilibrium" total gold concentration $C_{\mathrm{Au}}$ (eq.) by the equation $C_{\mathrm{Au}(\mathrm{I})}=1.5 C_{\mathrm{Au}}(\mathrm{eq})-.1.5 C^{\mathrm{n}} \mathrm{Au}$

In the solutions where the starting solution is gold(I), the gold(I) "equilibrium" concentrations are related to the initial and the equilibrium concentrations by $C_{\mathrm{Au}(\mathrm{I})}=1.5 C_{\mathrm{Au}}(\mathrm{eq})-.0.5 C_{\mathrm{Au}}^{0}$.

a. Solutions prepared from $\mathrm{Au}\left(\mathrm{NH}_{3}\right)_{4}{ }^{3+}$ with $\mathrm{Au}$

$\begin{array}{llllll}C_{\mathrm{NH}} & C_{\mathrm{Au}}^{0} & C_{\mathrm{Au}}(\mathrm{eq} .) & C_{\mathrm{Au}(\mathrm{I})} & E & E^{0}{ }_{1,0} \\ \mathbf{0 . 2 3 1} & \mathbf{0 . 0 0 0 9 3 0} & \mathbf{0 . 0 0 1 2 0 2} & \mathbf{0 . 0 0 0 4 0 8} & \mathbf{+ 4 4 9} & +\mathbf{5 7 4} \\ 0.216 & \mathbf{0 . 0 0 0 9 5 9} & \mathbf{0 . 0 0 1 1 4 9} & \mathbf{0 . 0 0 0 2 8 5} & \mathbf{+ 4 4 6} & \mathbf{+ 5 7 7} \\ \mathbf{0 . 0 8 5 1} & \mathbf{0 . 0 0 0 9 6 8} & \mathbf{0 . 0 0 1 1 1 8} & \mathbf{0 . 0 0 0 2 2 5} & \mathbf{+ 4 7 7} & \mathbf{+ 5 6 6} \\ \mathbf{0 . 0 3 6 9} & \mathbf{0 . 0 0 0 8 1 4} & \mathbf{0 . 0 0 0 9 5 4} & \mathbf{0 . 0 0 0 2 1 0} & \mathbf{+ 5 0 1} & \mathbf{+ 5 4 9}\end{array}$

b. Solutions prepared starting with gold(I)

$\begin{array}{lllllr}0.443 & \mathbf{0 . 0 0 1 0 9 2} & \mathbf{0 . 0 0 0 6 3 4} & 0.000405 & +383 & +541 \\ 0.248 & 0.001249 & 0.000649 & 0.000350 & +416 & +549 \\ 0.158 & 0.001148 & 0.000584 & 0.000302 & +473 & +586 \\ 0.0710 & 0.001258 & 0.000604 & 0.000277 & +499 & +573\end{array}$

c. Final potentials from redox titrations

$\begin{array}{lccc}0.906 & 0.000946 & +414 & +587 \\ 2.17 & 0.000800 & +319 & +542 \\ & & & E_{1,0}^{0}=+563 \pm 6 \mathrm{mV}\end{array}$ 


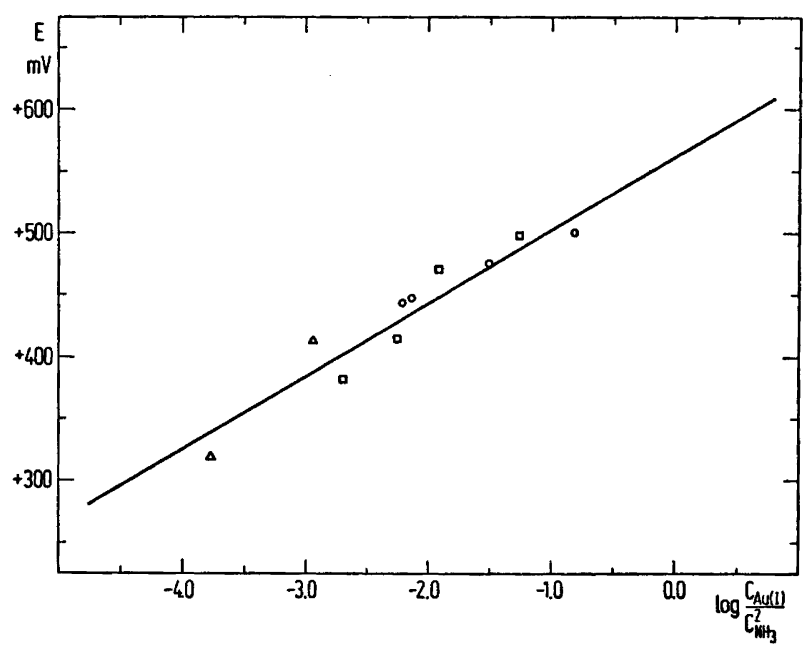

Fig. 1. Nernst plot of the gold(I), gold potentials in" $10 \mathrm{M}$ ammonium nitrate solutions with varying ammonia concentration with a gold electrode in solutions with equilibrium between gold(I) and gold(III). The straight line has the theoretical slope, $59.1 \mathrm{mV}$ for $25^{\circ} \mathrm{C}$.

O: Potentials in solutions equilibrated from the gold(III) side. $\square$ : Potentials in solutions equilibrated from the gold(I) side. $\triangle$ : Final potentials from redox titration experiments.

so that the results obtained in $10 \mathrm{M}$ ammonium nitrate at $25^{\circ} \mathrm{C}$ are the following

$\mathrm{Au}\left(\mathrm{NH}_{3}\right)_{2}++e^{-} \rightleftharpoons \mathrm{Au}+2 \mathrm{NH}_{3}$

$E_{1,0}^{0}=+563 \pm 6 \mathrm{mV}$

$\mathrm{Au}\left(\mathrm{NH}_{3}\right)_{4}{ }^{3+}+2 \mathrm{e}^{-} \rightleftharpoons \mathrm{Au}\left(\mathrm{NH}_{3}\right)_{2}{ }^{+}+2 \mathrm{NH}_{3}$

$E_{3,1}^{0}=+206 \pm 3 \mathrm{mV}$

$\mathrm{Au}\left(\mathrm{NH}_{3}\right)_{4}{ }^{3+}+3 \mathrm{e}^{-} \rightleftharpoons \mathrm{Au}+4 \mathrm{NH}_{3}$

$E_{3,0}^{0}=+325 \pm 3 \mathrm{mV}$

The standard deviations on the potentials seem to be high, but they are of the same magnitude as ordinarily obtained from measurements of gold potentials, ${ }^{22,24}$ except in case of the chloride, bromide, and thiocyanate systems. The situation in these systems is simpler than in the ammonia system because deprotonation, hydrolysis, and further decomposition of the tetramminegold(III) complex influence the result in this system. ${ }^{16,25}$ Contrary to what is the case for the gold(III) complex, $\mathrm{Au}(\mathrm{I})$ most likely is present exclusively as $\mathrm{Au}\left(\mathrm{NH}_{3}\right)_{2}+$ under the conditions of the measurements.

The data given in Table 3 show qualitatively that $\mathrm{Au}(\mathrm{III})$ ammonia solutions dissolve gold,

Table 4. Equilibrium between gold(I) and gold(III) in different ligand systems at $25^{\circ} \mathrm{C}$. In the thiocyanate, the bromide, and the chloride the equilibrium is

$\mathrm{AuX}-\mathrm{X}_{4}^{-}+2 \mathrm{Au}+2 \mathrm{X}^{-} \rightleftharpoons 3 \mathrm{AuX}_{2}^{-}$

and in the ammonia system

$\mathrm{Au}\left(\mathrm{NH}_{3}\right)_{4}{ }^{3+}+2 \mathrm{Au}+2 \mathrm{NH}_{3} \rightleftharpoons 3 \mathrm{Au}\left(\mathrm{NH}_{3}\right)_{2}+$

\begin{tabular}{|c|c|c|c|c|}
\hline & $\mathrm{SCN}^{-}$ & $\mathrm{Br}^{-}$ & $\mathrm{Cl}^{-}$ & $\mathrm{NH}_{3}$ \\
\hline$K_{3,1}$ & $4.8 \times 10^{-1}$ & $4.7 \times 10^{-6}$ & $1.8 \times 10^{-8}$ & $8 \times 10^{-13}$ \\
\hline Medium & $I \rightarrow 0$ & $I \rightarrow 0$ & $I \rightarrow 0$ & $10 \mathrm{M} \mathrm{NH}_{4} \mathrm{NO}_{3}$ \\
\hline Method & $\begin{array}{l}\text { Calc. } \\
\text { from potentials }\end{array}$ & $\begin{array}{l}\text { Direct } \\
\text { analyt. } \\
\text { determination }\end{array}$ & $\begin{array}{l}\text { Direct } \\
\text { analyt. } \\
\text { determination }\end{array}$ & $\begin{array}{l}\text { Calc. } \\
\text { from potentials }\end{array}$ \\
\hline Reference & $\begin{array}{l}\text { Pouradier and } \\
\text { Gadet }^{8}\end{array}$ & $\begin{array}{l}\text { Evans and } \\
\text { Lingane }^{4}\end{array}$ & Lingane $^{1}$ & $\begin{array}{l}\text { Present } \\
\text { investigation }\end{array}$ \\
\hline
\end{tabular}

Acta Chem. Scand. A 28 (1974) No. 7 
and that diamminegold(I) solutions disproportionate to $\mathrm{Au}(\mathrm{III})$ and gold. But as the gold(III) system is rather undefined and probably not in equilibrium with gold, these data were not used for a direct calculation of the equilibrium constant $K_{3,1}$ of the reaction:

$$
\mathrm{Au}\left(\mathrm{NH}_{3}\right)_{4}{ }^{3+}+2 \mathrm{Au}+2 \mathrm{NH}_{3} \rightleftharpoons 3 \mathrm{Au}\left(\mathrm{NH}_{3}\right)_{2}{ }^{+}
$$

A reliable value for this constant is calculated from the standard potentials to be $10^{-12.1}$ in 10 $\mathrm{M}$ ammonium nitrate at $25^{\circ} \mathrm{C}$.

This constant is compared in Table 4 with the corresponding constants for the three aniono systems previously investigated. It will be seen that $K_{3,1}$, as could be expected, increases with the tendency of the ligands to be oxidized in the series: $\mathrm{SCN}^{-}>\mathrm{Br}^{-}>\mathrm{Cl}^{-}>\mathrm{NH}_{3}$. This means that the gold(III) ammonia complex is stabilized relatively to the gold(I) complex. However, the standard potentials show that this stabilization of the gold(III) ammonia complex is not sufficient to change the order of stabilities of the gold complexes which in both valence steps are: $\mathrm{NH}_{3}>\mathrm{SCN}^{-}>\mathrm{Br}^{-}>\mathrm{Cl}^{-}$.

The standard potentials of the gold amines give only relative values for the stability constants of the complexes. As mentioned in the introduction, the standard potential of the aqua couples cannot be directly measured but only estimated from empirical rules. Using the value $+2.12 \mathrm{~V}$ for the $\mathrm{Au}\left(\mathrm{H}_{2} \mathrm{O}\right)_{2}{ }^{+}, \mathrm{Au}$ couple previously suggested by one of the authors, ${ }^{18,14,26}$ one gets the value $\log \beta_{2}=26.5$ for $\mathrm{Au}\left(\mathrm{NH}_{3}\right)_{2}+$. This value is close to J. Bjerrum's prediction in $1950:^{14} \log \beta_{2}=27$. Other suggestions for the $\mathrm{Au}\left(\mathrm{H}_{2} \mathrm{O}\right)_{2}+, \mathrm{Au}$ couple are considerably lower: Latimer ${ }^{23}$ together with Hancock and Finkelstein ${ }^{11}$ gives a value close to $+1.70 \mathrm{~V}$, which leads to $\log \beta_{2}=19.5$. Improved attempts to solve this discrepancy will appear in a forthcoming paper in this series.

Comparing both of these values with those for the two other diammine complexes in group I B of the Periodic Table: $\mathrm{Cu}\left(\mathrm{NH}_{3}\right)_{2}{ }^{+}, \log \beta_{2}=$ $10.9,{ }^{15}$ and $\mathrm{Ag}\left(\mathrm{NH}_{3}\right)_{2}{ }^{+}, \log \beta_{2}=7.1,{ }^{27}$ one finds the usual trend within this group.

\section{REFERENCES}

1. Lingane, J. J. J. Electroanal. Chem. 4 (1962) 332.
2. Pouradier, J., Gadet, M. -C. and Chateau, H. J. Chim. Phys. 62 (1965) 203.

3. Tschappat, C. and Robert, E. Helv. Chim. Acta 37 (1954) 333.

4. Evans, D. H. and Lingane, J. J. J. Electroanal. Chem. 6 (1963) 1.

5. Grube, G. and Morita, T. Z. Electrochem. 38 (1932) 120.

6. Pouradier, J. and Gadet, M.-C. J. Chim. Phys. 62 (1965) 1181.

7. Bjerrum, N. and Kirschner, Aa. Kgl. Dan. Vidensk. Selsk. Skr., Naturv. og Mat. Afd. (8) 5 (1918) No. 1.

8. Pouradier, J. and Gadet, M.-C. J. Chim. Phys. 63 (1966) 1467.

9. Peshchevitskii, B. I., Kazakov, V. P. and Erenburg, A. M. Russian J. Inorg. Chem. 8 (1963) 437.

10. Jørgensen, C. K. and Pouradier, J. J. Chim. Phys. 67 (1970) 124.

11. Hancock, R. D. and Finkelstein, N. P. Inorg. Nucl. Chem. Lett. 7 (1971) 477.

12. Erenburg, A. M. and Peshchevitskii, B. I. Russian J. Inorg. Chem. 14 (1969) 1429.

13. Hawkins, C. J., Mønsted, O. and Bjerrum, J. Acta Chem. Scand. 24 (1970) 1059.

14. Bjerrum, J. Chem. Rev. 46 (1950) 381.

15. Bjerrum, J. Kgl. Dan. Vidensk. Selsk., Mat.Phys. Medd. 12 (1934) No. 15.

16. Skibsted, L. H. and Bjerrum, J. Acta Chem. Scand. A 28 (1974) 740.

17. Gjaldbæk, J. K. Kgl. Dan. Vidensk. Selsk., Mat.-Phys. Medd. 5 (1924) No. 9.

18. Convington, A. K. In Durst, R. A., Ed., Ion-Selective Electrodes. National Bureau of Standards Special Publication 314, Washington 1969.

19. Bates, R. G. Determination of $p H$, Wiley, New York 1964.

20. Robinson, R. A. and Stokes, R. H. Electrolyte Solutions, 2nd Ed., Butterworths, London 1959.

21. Bjerrum, N. Bull. Soc. Chim. Belg. 57 (1948) 432.

22. Hancock, R. D., Finkelstein, N. P. and Evers, A. J. Inorg. Nucl. Chem. 34 (1972) 3747.

23. Latimer, W. M. Oxidation Potentials, 2nd Ed., Prentice-Hall, London 1952.

24. Kazakov, V. P., Lapshin, A. I. and Peshchevitskii, B. I. Russian J. Inorg. Chem. 9 (1964) 708.

25. Weitz, E. Justus Liebigs Ann. Chem. 410 (1915) 117.

26. Bjerrum, J., George, R. S., Hawkins, C. J. and Olson, D. C. Proceedings of the Symposium on Coordination Chemistry, Tihany 1964, Akadémiai Kiadó, Budapest 1965.

27. Bjerrum, J. Metal Ammine Formation in Aqueous Solution, 2nd Ed., Haase and Son, Copenhagen 1957.

Received March 11, 1974.

Acta Chem. Scand. A 28 (1974) No. 7 